\title{
Immediate Release Capsule Dosage Form
}

National Cancer Institute

\section{Source}

National Cancer Institute. Immediate Release Capsule Dosage Form. NCI Thesaurus. Code C142247.

A capsule dosage form that is designed to release its active and/or inert ing redient(s) upon administration with no enhanced, delayed or extended release effect. 